DEPARTMENT OF THE INTERIOR

UNITED STATES GEOLOGICAL SURVEY

GEOLOGIC MAP OF THE

DAVIS VALLEY QUADRANGLE

AND PART OF THE

CORDINER PEAKS QUADRANGLE,

PENSACOLA MOUNTAINS,

ANTARCTICA

By Arthur B. Ford, Dwight L. Schmidt, and Walter W. Boyd, Jr.

Prepared by the

U.S. GEOLOGICAL SURVEY

under the auspices of the

NATIONAL SCIENCE FOUNDATION 


\section{GEOLOGIC MAP SYMBOLS}

COMMONLY USED ON MAPS OF THE UNITED STATES GEOLOGICAL SURVEY (Special symbols are shown in explanation)

Contact-Dashed where approximately located; short dashed where inferred; dotted where concealed

$1^{45}$

Contact_-Showing dip; well exposed at triangle

Fault-Dashed where approximately located; short dashed where inferred; dotted where concealed

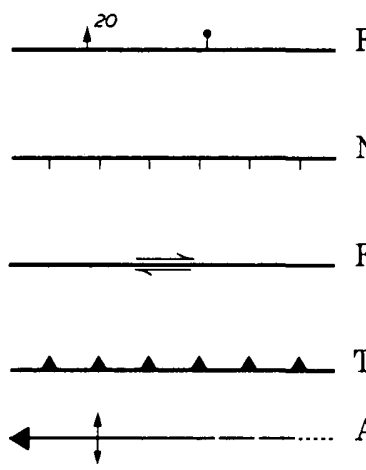

Fault, showing dip-Ball and bar on downthrown side

Normal fault-Hachured on downthrown side

Fault-Showing relative horizontal movement

Thrust fault-Sawteeth on upper plate

Anticline-Showing direction of plunge; dashed where approximately located; dotted where concealed

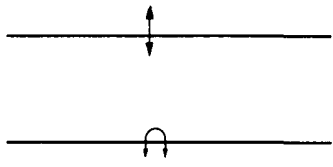

Asymmetric anticline-Short arrow indicates steeper limb

Overturned anticline--Showing direction of dip of limbs

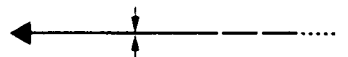

Syncline-Showing direction of plunge; dashed where approximately located dotted where concealed

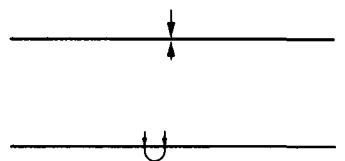

Asymmetric syncline-Short arrow indicates steeper limb

Overturned syncline-Showing direction of dip of limbs

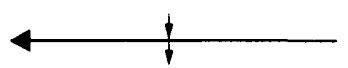

Monocline-Showing direction of plunge of axis

$\rightarrow \rightarrow^{20} \quad$ Minor anticline-Showing plunge of axis

$\hookrightarrow{ }^{60} \quad$ Minor syncline-Showing plunge of axis
Strike and dip of beds-Ball indicates top of beds known from sedimentary structures

$\stackrel{70}{\perp}$ Inclined $\oplus$ Horizontal

+ Vertical 40 Overturned

Strike and dip of foliation

20 Inclined $\rightarrow$ Vertical $\rightarrow$ Horizontal

Strike and dip of cleavage

15 Inclined $\longmapsto$ Vertical $F$ Horizontal

Bearing and plunge of lineation

15 Inclined - Vertical $\longrightarrow$ Horizontal

Strike and dip of joints

40 Inclined $\rightarrow$ - Vertical + Horizontal

Note: Planar symbols (strike and dip of beds, foliation or schistosity, and cleavage) may be combined with linear symbols to record data observed at same locality by superimposed symbols at point of observation. Coexisting planar symbols are shown intersecting at point of observation.

Shafts

$\square$ Vertical Inclined

Adit, tunnel, or slope

$\succ$ Accessible $\quad>$ Inaccessible

$x$ Prospect

Quarry

Active Abandoned

Gravel pit

$X$ Active $\quad \not$ Abandoned

Oil wells

$\circ$ Drilling $\phi$ Shut-in $\phi$ Dry hole,

Gas Show of gas abandoned

- Oil $\quad$ Show of oil 


\title{
GEOLOGY OF THE DAVIS VALLEY QUADRANGLE AND PART OF THE CORDINER PEAKS QUADRANGLE, PENSACOLA MOUNTAINS, ANTARCTICA
}

\author{
By Arthur B. Ford, Dwight L. Schmidt, and Walter W. Boyd, Jr. ${ }^{1}$
}

\section{INTRODUCTION}

The area that includes the Davis Valley quadrangle and part of the Cordiner Peaks quadrangle in the Pensacola Mountains was first seen and photographed on January 13, 1956, on a U.S. Navy transpolar flight from McMurdo Sound. An International Geophysical Year (IGY) oversnow traverse party from Ellsworth Station reached Cairn Ridge, near Dufek Massif, December 9, 1957, during the first exploration of the inner margins of the Filchner and Ronne Ice Shelves (Neuburg and others, 1959). Trimetrogon aerial mapping photography was obtained by the U.S. Air Force in January 1958, at which time nearly the full extent of the Pensacola Mountains was first seen.2

Geological, geophysical, and geodetic surveys of the entire map area, as well as over many other parts of the Pensacola Mountains, were made by the U.S. Geological Survey during the 1965-66 field season (Huffman and Schmidt, 1966). The surveys used close support of U.S. Army UH-1 B turbine helicopters operating from a base camp in the central Neptune Range, where the field party was placed by U.S. Navy LC-130F (Hercules) aircraft from McMurdo Station. This work completed the geologic mapping of the entire $540-\mathrm{km}$-long chain of the Pensacola Mountains, a project begun in 1962-63 at the south end of the mountains (Schmidt and Ford, 1969). Additional geologic studies were made in January 1974 in the Cordiner Peaks (Cameron and Ford, 1974) during investigations of possible ice-runway aircraft landing sites by the U.S. Army Cold Regions Research and Engineering Laboratory (Kovacs and Abele, 1974).

The major geologic feature of the area shown on this map is the northern part of the Dufek intrusion (Ford and Boyd, 1968), an immense differentiated stratiform mafic igneous body that was discovered in 1957 by an IGY traverse party visiting Dufek Massif, a northern range of the Pensacola Mountains (Aughenbaugh, 1961; Walker, 1961; Neuburg and others, 1959). Time limitations and the presence of crevasse fields on the Jaburg Glacier limited the IGY studies to lower parts of the northern escarpment of

\footnotetext{
'Present address, Geological Survey of Finland, Helsinki

2 Aerial photographs of the Pensacola Mountains can be ordered from the U.S. Geological Survey, National Center, Reston, Va 22092.
}

Dufek Massif. Our 1965-66 studies showed that the intrusion makes up all of Dufek Massif and virtually all of the Forrestal Range (Ford and others, 1978). Geophysical surveys show that most of the body is covered by ice sheets adjoining the ranges and that its areal size is of the order of half that of the Bushveld intrusion of South Africa (Behrendt and others, 1974).

Access to this remote part of the continent is difficult except by ski-equipped aircraft. Although the ice terrain near Dufek Massif is suitable for ski-plane landings, aircraft operations are commonly hindered by adverse weather conditions. Our two seasons' experience in the area indicates that, at least in the summer months, the likelihood of poor visibility from fog and low clouds is the major factor limiting aircraft activity. Winds are generally slight along the northern escarpment of Dufek Massif. Summer temperatures during our work near Dufek Massif generally ranged from about $-16^{\circ} \mathrm{C}\left(4^{\circ} \mathrm{F}\right)$ to $-3^{\circ} \mathrm{C}$ $\left(26^{\circ} \mathrm{F}\right)$ and averaged about $-8^{\circ} \mathrm{C}\left(18^{\circ} \mathrm{F}\right)$.

Work on the Dufek intrusion in 1965-66 was chiefly by A. B. Ford and W. W. Boyd, Jr. Study of the sedimentary country rocks in the Cordiner Peaks and Spanley Rocks was mainly by D. L. Schmidt and W. H. Nelson and was continued in the Cordiner Peaks in January 1974 by Ford.

This report briefly outlines geologic relations and reviews work done in the area of the map sheet and adjacent regions.

Acknowledgments. - This work was part of the U.S. Antarctic Research Program of the Office of Polar Programs, National Science Foundation. General logistic and fixed-wing aircraft support was provided by the U.S. Navy Air Development Squadron Six. Helicopter support was provided by the U.S. Army Aviation Detachment. We gratefully acknowledge the help of all support personnel, of Jerry Huffman, National Science Foundation, in coordinating the field logistical support, and the assistance by Steven W. Nelson in laboratory studies related to this project.

\section{SYNOPSIS OF GEOLOGIC STUDIES}

The map area is near the north end of the Pensacola Mountains, a mountain group that forms part of the transcontinental chain of the Transantarctic Mountains (fig. $1 B$ ). Principal ranges of the Pensacola Mountains are shown in figure $1 A$. 

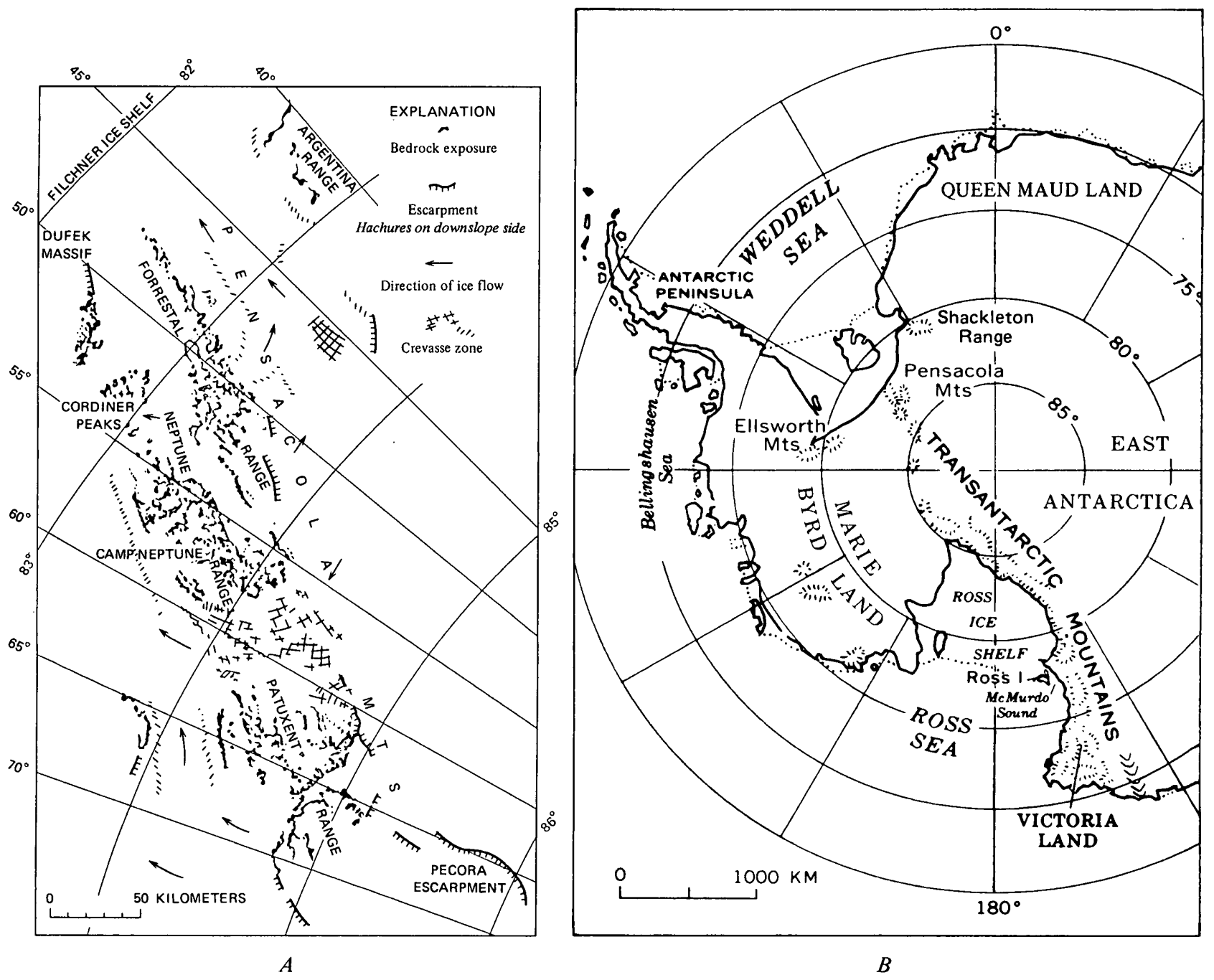

Figure 1. - Index maps. $A$, Major ranges of the Pensacola Mountains and location of Camp Neptune. $B$, Location of Pensacola Mountains in Antarctica.

The principal rock exposures in the mapped area are units of the Dufek intrusion. This layered igneous body, which is Jurassic in age, intruded moderately to highly deformed Precambrian to Permian sedimentary rocks during the time of emplacement of sills of Ferrar Dolerite throughout the Transantarctic Mountains (Grindley, 1963). The poorly exposed sedimentary country rocks are visible only in generally small and isolated nunataks in the southern part of the map area. Relations between sedimentary formations are inferred to be the same as in the Neptune Range, about $40 \mathrm{~km}$ south of Dufek Massif, where the units are much better exposed (Schmidt and others, 1978). General geologic relations between ranges of the Pensacola Mountains are shown on the 1:1,000,000-scale map of Schmidt and Ford (1969). Formal rock-stratigraphic nomenclature for the Dufek intrusion is presented by Ford (1976) and for sedimentary rocks is given by Schmidt and others (1964, 1965), Schmidt and Ford (1969), and
Williams (1969). The summary below is drawn largely from these sources.

\section{SEDIMENT ARY ROCKS}

The sedimentary units exposed in this area belong chiefly to the youngest of three depositional sequences known to the south in the Neptune Range. In the Neptune Range the sequences are clearly seen to be separated by angular unconformities. Fossils are scarce in or absent from most units, but available paleontologic and radiometric age data suggest that ages of the sequences are (1) Precambrian, (2) Middle and Late(?) Cambrian, and (3) Ordovician(?) to Permian. Rocks correlative with the oldest of these sequences are exposed only on a few small nunataks near the southwest corner of the map area but probably are much more extensive under the cover of ice. Correlatives of the second sequence are not exposed but could occur beneath the ice cover. Rocks of the third sequence form the principal nunataks south of the Dufek intrusion in this area. 
The Patuxent Formation, of late Precambrian age (Schmidt and others, 1978), makes up the oldest sequence and consists in the Neptune Range of at least about $10,000 \mathrm{~m}$ of metasubgraywacke and slate locally interbedded with voluminous basaltic and felsic volcanic materials. Radiometric dating (Eastin and Faure, 1972) suggests that some of these volcanic units may be as old as $1,210 \mathrm{~m} . \mathrm{y}$. Diabase sills locally intrude the formation. The igneous units of the formation are not known in the Davis Valley and Cordiner Peaks quadrangles. In the Schmidt Hills quadrangle, the Patuxent unconformably underlies Cambrian limestone. The Patuxent sediments were deposited in a high-energy environment, probably a volcanically active eugeosyncline, as indicated by lithologies and abundant sedimentary structures such as graded bedding, channel features, and sole markings. The Patuxent was widely metamorphosed to the greenschist facies during an orogeny near the end of the Precambrian.

The second sequence, which is not known to occur in and may be absent from the mapped area, consists of a fossiliferous Middle Cambrian (Palmer and Gatehouse, 1972) limestone and overlying silicic volcanic and clastic sedimentary units that have a composite thickness of at least $700 \mathrm{~m}$. Some of the units are known to thin northward from the southern Neptune Range, and as none are exposed in adjoining areas, they are believed to be absent and are not shown in the cross sections. Accordingly, the single angular unconformity shown is equivalent to the two preDevonian angular unconformities that are known to exist below the Neptune Group in the central and southern parts of the Neptune Range.

The third sequence, which is at least $4,000 \mathrm{~m}$ thick in the Neptune Range, consists in ascending order of the Neptune Group, Dover Sandstone, Gale Mudstone, and the Pecora Formation. The Neith Conglomerate, a coarse, poorly sorted unit at the base of the Neptune Group, is exposed in the map area only on small nunataks of the Spanley Rocks. Although its upper contact is not exposed, the unit probably underlies the Elbow Formation. An upper sandy part of the Neith probably correlates with the Elliott Sandstone, and a lower conglomeratic part with the Brown Ridge Conglomerate, in the type area of the Neptune Group. The Neith may be as much as $1,000 \mathrm{~m}$ thick in the Schmidt Hills quadrangle. The Dover Sandstone, which overlies the Neptune Group, is disconformably overlain by the Gale Mudstone, a diamictite of probable continental glacial origin (Schmidt and Williams, 1969; Schmidt and Friedman, 1974). The contact between the Gale and Dover is well exposed on Rosser Ridge. The Pecora Formation is not exposed in the map area. Although its contact with the underlying Gale is not exposed in the Pensacola Mountains, the two formations appear to be concordant. Rare diagnostic fossils indicate a Devonian age for the Dover and a Late Permian age for the Pecora (Schopf,
1968). Depositional environments ranged from high energy in late orogenic to early postorogenic time (Ordovician? to Silurian?) during deposition in local basins of the basal part of the Neptune Group, to low energy during Devonian to Permian deposition of later sediments, which probably took place on a slowly subsiding continental shelf or terrestrial plain.

\section{TECTONIC EVENTS}

The Pensacola Mountains lie in a mobile belt with a long record of recurrent deformation. The folding of angular unconformities between the three sedimentary sequences shows clearly that episodes of deformation in this region were superimposed. The area lies at or near the intersection of the multiply deformed Transantarctic Mountains fold belt and a younger, probably early Mesozoic, fold belt adjoining the Weddell Sea (Ford, 1972).

Major orogenies in the Pensacola Mountains occurred (1) near the end of the Precambrian; (2) in the early Paleozoic, probably in Late Cambrian and Ordovician time; and (3) in the Triassic. Weak deformation during or after the Jurassic may be indicated by the broad synclinal flexure of the layered Dufek intrusion and by the pervasive system of microshears in the Dufek rocks that parallel a regional fracture pattern (Ford, 1968). The high-angle Enchanted Valley fault zone along the northern base of Dufek Massif may be related to Cenozoic uplift of the Pensacola Mountains.

The two pre-Devonian orogenies in the Pensacola Mountains probably correspond to the Beardmore (580-650 m.y.) and Ross (500-530 m.y.) orogenies, which were widespread in the Transantarctic Mountains (Elliot, 1975). The third major event, locally termed the Weddell orogeny (Ford, 1972), is not recorded by folding in other parts of the Transantarctic Mountains. This event is dated in the Pensacola Mountains as having occurred at some time between the Late Permian and Middle Jurassic. However, the change in paleoslope directions at the beginning of Triassic time in other parts of the Transantarctic Mountains is attributed to uplift in the Pensacola Mountains (Barrett and others, 1972), which thus probably dates the orogeny as Early Triassic. Deformation of about this age is widely recorded elsewhere near the Weddell Sea (Craddock, 1972; Dalziel and Elliott, 1973).

All major folds shown on the map were produced during the Triassic orogeny. Intensity of the folding varies widely in different parts of the Pensacola Mountains. In the Neptune Range, rocks of the third sedimentary sequence in places are folded isoclinally and in other places are little deformed. In the Cordiner Peaks area, the folds are open and upright. The rocks are moderately folded about gently plunging or horizontal axes trending about N. 10-15 $\mathrm{E}$. The large anticline at the west end of Rosser Ridge has an amplitude of at least $400-500 \mathrm{~m}$ and a half wavelength of about 4-5 km. Coarse well-developed axial- 
plane cleavage in the Gale Mudstone suggests that * folds are overturned a few degrees westward (fig. 2). Joint patterns show crudely developed orthogonal symmetry geometrically related to major folds.

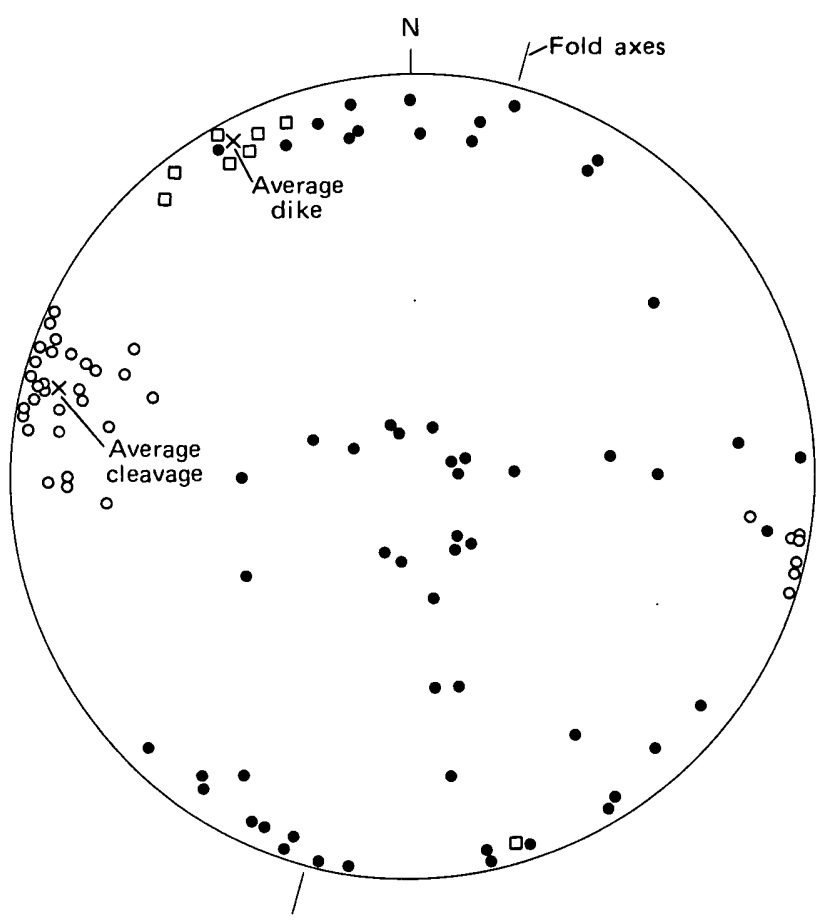

Figure 2 - Lower-hemisphere stereographic projection of poles to cleavage (circles), joints (dots), and basalt dikes (squares) in the Cordiner Peaks. X's mark average cleavage and dike poles. After Ford (1974)

The Patuxent Formation is much more intensely folded than the Paleozoic rocks but is poorly exposed in the map area. In the Neptune Range, axial trends of folds in the Patuxent generally parallel those of the younger rocks.

\section{MAFIC DIKES}

Tholeiitic basalt and diabase dikes are locally abundant in the eastern and central parts of Rosser Ridge where they cut the Dover Sandstone and Gale Mudstone. Their general orientation of about N. $45^{\circ} \mathrm{E}$. in strike and steep southeastward dip shows little apparent relation to the dominant joint and cleavage fracture systems (fig. 2). The dikes range in thickness from a few centimeters to about $6 \mathrm{~m}$. Dikes thicker than about $1 \mathrm{~m}$ generally have diabasic interiors. Devitrified glassy selvages are common. The dikes are nonporphyritic and appear homogeneous except for grain-size and textural variations related to distance from contacts. The rocks are commonly slightly altered, as indicated by presence of minor amounts of calcite and other secondary minerals after plagioclase and pyroxene.

The dikes are not deformed, and thus they postdate the Triassic orogeny in this area. In the entire Pensacola Mountains, basalt dikes known to be of
Triassic or younger age occur only on Rosser Ridge, one of the nunataks of Paleozoic country rock nearest to the Dufek intrusion. (Basaltic dikes are also known in the Argentina Range but are dated only as Cambrian or younger, and theoleiitic basalt and diabase sills occur in the Pecora Escarpment where they intrude the Permian Pecora Formation.) The geographic distribution of the dikes suggests that they are related to the Dufek intrusion (Ford, 1974); therefore, the dikes are tentatively assigned a Jurassic age. If the dikes were emplaced at the same time as the Dufek, their slight alteration can be interpreted as being a contact effect during slow cooling of the Dufek magma.

\section{THE DUFEK INT RUSION}

The first work on the Dufek intrusion by Aughenbaugh (1961) and Walker (1961) demonstrated the similarity of the body to other major layered mafic intrusions. The similarity was documented more strongly by our 1965-66 work, which showed the presence of a differentiation trend toward strong iron enrichment in the upper part of the body and a final concentration of a granophyric residuum (Ford and Boyd, 1968; Ford, 1970). The differentiation trend generally follows that of other stratiform complexes summarized by Wager and Brown (1968). Our work has emphasized the sedimentlike nature of most of the layered rocks. Owing to the stratigraphic character of the layered igneous succession, our field studies were carried out largely with techniques used in the study of a stratified sedimentary sequence. In this investigation, 10 partial stratigraphic sections were measured by altimetry and hand leveling in the area of Dufek Massif, and 11 were measured in the Forrestal Range. Those in the Forrestal Range are all in the area south of this map area. Most sections within each range are intercorrelated using one or more conspicuous marker layers or horizons. All major areas of outcrop were visited or viewed closely from aircraft. Approximately 1,000 samples collected are representative of all major exposed units. Nearly a third of the samples were oriented for petrofabric and paleomagnetic study.

\section{PETROLOGIC NOMENCLATURE}

The layered igneous rocks formed by accumulation of settled crystals in a mush on the floor of a magma chamber. Rocks of this origin are termed "cumulates," and their textures and structures reflect sedimentary processes controlled by gravity, hydraulic parameters of the magma, and the presence or absence of currents (Jackson, 1971). Following usage in sedimentary petrology, which distinguishes detrital grains from cement, the cumulus (detrital) phases form the framework of the rock, and the postcumulus (cement) phases are primary materials that crystallized in places they now occupy.

Cumulates are named by prefixing names of settled minerals in order of decreasing abundance (Jackson, 1967, p. 23). The principal cumulus phases in 
the Dufek intrusion are plagioclase, pyroxenes in the series augite-ferroaugite, pyroxenes in the series bronzite-inverted pigeonite, and opaque oxides. Preliminary results of studies in progress on the chemistry and mineralogy of opaque oxides indicate that the most common phases are titaniferous magnetite and ferrian ilmenite in composite grains that probably represent unmixing of original homogeneous titaniferous magnetite (Himmelberg and Ford, 1975, 1977). For brevity, the opaque oxides are referred to simply as magnetite. Phases that are cumulus in some rocks are postcumulus in others. Quartz and K-feldspar are known to be only postcumulus and so are not included in the cumulate terminology. Two pyroxene-plagioclase cumulate is the predominant lithology in the lower part of the intrusion, and two pyroxene-plagioclase-magnetite cumulate predominates in the upper part.

Rock names used in the map explanation and text are of two types based on (1) total mode of the rock and (2) types and proportions of cumulus minerals. In our field studies, rocks were mapped on the basis of total mode, in which cumulus and postcumulus minerals are not distinguished. The map units are given formal rock-stratigraphic names using standard noncumulate igneous rock nomenclature. The cumulate terminology of Jackson $(1967,1971)$, however, is used in the explanation and text for description of the rocks. Where proportions of cumulus minerals are not known, or not otherwise indicated, conventional names are prefixed, as in "gabbroic cumulate" or "anorthositic cumulate."

\section{STRATIGRAPHIC NOMENCLATURE}

The rock-stratigraphic nomenclature and stratigraphy of the intrusion are discussed by Ford (1976) and are shown in figure 3 . The layered succession of rocks is incompletely exposed and is estimated on the basis of structure and geophysical evidence to be of the order of $8-9 \mathrm{~km}$ thick. A lower part of the body is exposed in Dufek Massif. The composite section of this part, about $1,800 \mathrm{~m}$ thick, is referred to as the "Dufek Massif section." The upper part of the body is exposed in the Forrestal Range. The composite section of this part, about $1,700 \mathrm{~m}$ thick, is referred to as the "Forrestal Range section." An ice-covered interval, termed the "Sallee Snowfield section," between the two exposed-rock sections is estimated to be $2-3 \mathrm{~km}$ thick. Geophysical studies by Behrendt and others (1974) suggest that an unexposed basal section is 1.8-3.5 km thick. An unknown but probably small thickness of rock was eroded from the upper part of the body.

Fine- to coarse-grained gabbro near the contact and dike rocks ranging from aplite to gabbroic pegmatite are the principal nonstratified rocks of the intrusion. The contact gabbro is of noncumulus origin and probably forms an envelope around the layered sequence. It is exposed at only a single locality near Mount Lechner in the southern Forrestal Range.
All the stratified rocks are included in the Forrestal Gabbro Group, which is divided into four formations, from base to top, the Walker Anorthosite, Aughenbaugh Gabbro, Saratoga Gabbro, and Lexington Granophyre. Distinctive mappable units of the Aughenbaugh and Saratoga are recognized as members. Most members consist of one or more mineralgraded cumulate layers. Two members of the Saratoga are characterized by an abundance of cognate inclusions composed of noncumulus anorthosite and leucogabbro. The chief lithologic difference between the Aughenbaugh and Saratoga is the much greater abundance of cumulus magnetite in the Saratoga. Other mineralogic differences are discussed below.

MINERAL DISTRIBUTION AND COMPOSITION

The Forrestal Gabbro Group contains highly variable proportions of cumulus minerals. The stratigraphic distribution of these minerals and of postcumulus minerals is shown in figure 3 . Cumulates of gabbroic composition generally consist of subequal amounts of plagioclase and pyroxene. Magnetite is a chief modal variant occurring in only minor amounts near the top of the Aughenbaugh Gabbro and as a major constituent throughout the Saratoga Gabbro. In many thin layers and lenses in the Saratoga, it is the only or the greatly predominant mineral, commonly at the base of thicker mineral-graded layers. The upward stratigraphic increase in amounts of magnetite in the intrusion as a whole results in an overall upward increase in average rock density (Ford and Nelson, 1972) and in great differences in aeromagnetic intensities measured over the two ranges (Behrendt and others, 1974). Layers in which cumulus plagioclase is concentrated occur throughout the intrusion, as in the Walker Anorthosite, Spear Anorthosite Member, and Stephens Anorthosite Member; whereas layers in which cumulus proxene is concentrated occur only in the Dufek Massif section, as in the Neuburg ${ }^{3}$ and Frost Pyroxenite Members. Most of these layers are of mineral-graded type. Apatite is a common though minor cumulus phase in the highest cumulates of the Saratoga Gabbro and is a noncumulus constituent of the Lexington Granophyre. Quartz and K-feldspar are minor postcumulus minerals in the upper part of the Saratoga and are dominant constituents of the Lexington.

The chemistry of bulk rocks and of individual mineral phases shows progressive stratigraphic changes generally similar to those of other stratiform mafic intrusions described by Wager and Brown (1968). As determined by preliminary optical and X-ray studies, plagioclase compositions range from about An $80-85$ in anorthositic cumulates near the base of the Dufek Massif section to about $\mathrm{An}_{45-55}$ in gabbroic rocks and granophyre near the top of the Forrestal Range section (Ford and Boyd, 1968). Electron microprobe

\footnotetext{
${ }^{3}$ This name, derived from Neuburg Peak, was incorrectly spelled "Neuberg" in previous reports (Ford, 1976; Himmelberg and Ford, 1976).
} 


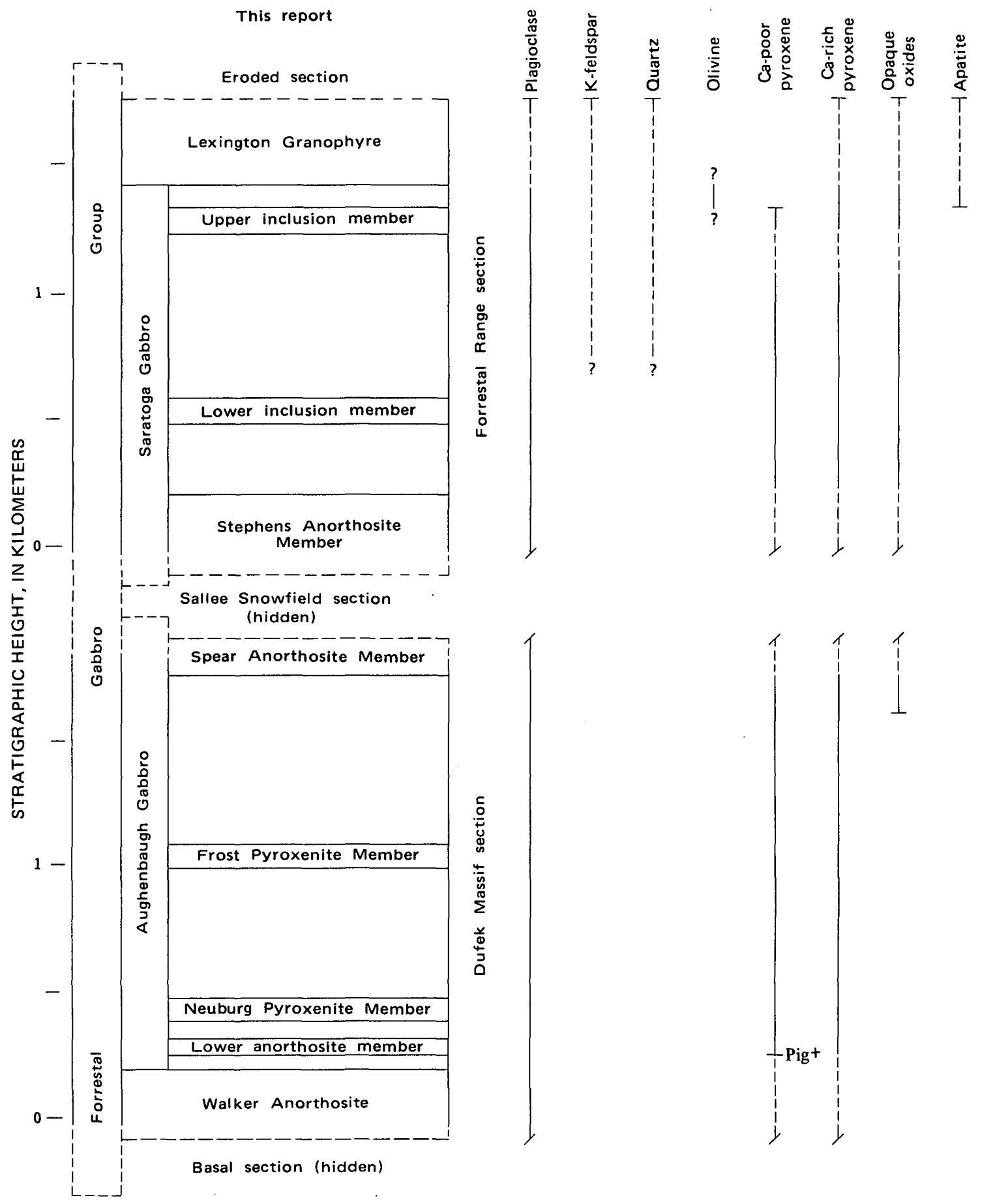

Figure 3 - Rock-stratigraphic nomenclature of the Dufek intrusion and distribution of minerals. Solid vertical lines, cumulus minerals; dashed lines, noncumulus minerals (in granophyre) and postcumulus minerals. Pigt, lowest occurrence of inverted cumulus pigeonite. After Ford (1976) and Himmelberg and Ford (1976) 


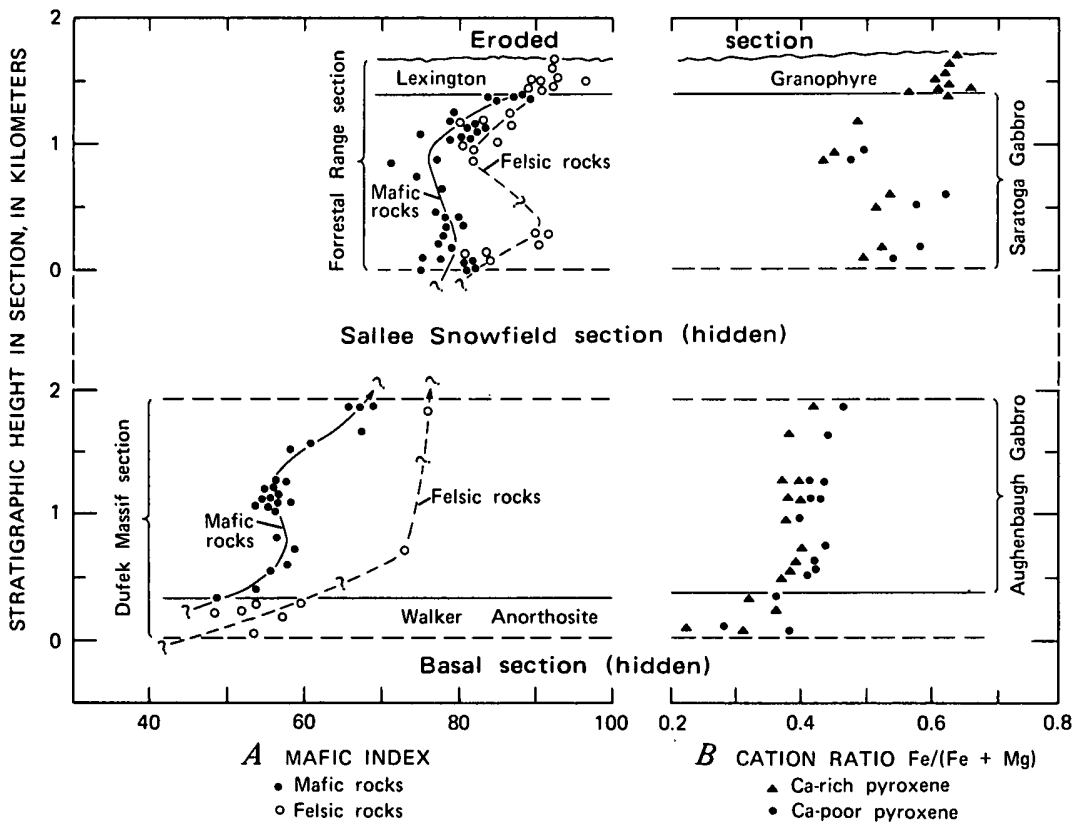

Figure 4 - Stratigraphic variations in chemical composition in the Dufek intrusion. $A$, Mafic index, $\left(\mathrm{FeO}+\mathrm{Fe}_{2} \mathrm{O}_{3}\right) \times 100 /(\mathrm{Fe} 0+$ $\mathrm{Fe}_{2} \mathrm{O}_{3}+\mathrm{Mg} 0$ ), of whole rocks (after Ford, 1970). $B$, Cation ratio, $\mathrm{Fe} /(\mathrm{Fe}+\mathrm{Mg}$ ), of the two pyroxene series (after Himmelberg and Ford, 1976).

analyses show that $\mathrm{Ca}$-rich cumulus pyroxenes in the series augite-ferroaugite range from $\mathrm{Ca} 36.4$ $\mathrm{Mg}_{48.7} \mathrm{Fe}_{14.9}$ to $\mathrm{Ca}_{30.0} \mathrm{Mg}_{23.5} \mathrm{Fe}_{46.5}$, and that Ca-poor cumulus pyroxenes in the series bronziteinverted pigeonite range from $\mathrm{Ca}_{3.5} \mathrm{Mg}_{69.1} \mathrm{Fe}_{27.4}$ to $\mathrm{Ca}_{11.4} \mathrm{Mg}_{34.0} \mathrm{Fe}_{54.6}$ (Himmelberg and Ford, $1973,1976)$. The upward stratigraphic increase in the ratio $\mathrm{Fe} /(\mathrm{Fe}+\mathrm{Mg})$ in both pyroxene series and the increase in modal magnetite are reflected in the general upward increase in the mafic index of bulkrock compositions (fig. 4). Although major-element contents of the oxide minerals show no regular variation with height, the minor elements vanadium and aluminum in ilmeno-magnetites generally decrease with height and thus are useful indicators of fractionation trends during the stage of oxide-mineral crystallization (Himmelberg and Ford, 1977).

\section{FELSIC DIKES}

Dikes of aplite, felsic pegmatite, and less common alaskite, leucogabbro, and gabbroic pegmatite occur sporadically throughout the Dufek intrusion and at many stratigraphic levels in the layered sequence. Zoning occurs locally. Dikes are more abundant in the Forrestal Range than in Dufek Massif. They are mostly vertical to subvertical and in places pinch out downward. Thicknesses of different dikes range from a few millimeters to several meters. Compositions of dikes seem to show changes related to stratigraphy and compositional changes of cumulate-host rocks, which suggests that they formed by the filling of fractures with late intercumulus liquids from local sources at various stages during consolidation of the intrusion (Ford, 1970). Granophyric dikes high in the intrusion may be related to development of the Lexington Granophyre at the end stage of differentiation.

\section{REGIONAL CORRELATION}

Sedimentary formations in the Pensacola Mountains are apparently correlatable for great distances in the Transantarctic Mountains and probably in the Ellsworth Mountains. All sedimentary units of this area probably are part of the Beacon Supergroup, a thick platform sequence of mainly arenaceous rocks ranging in age from Devonian or older to Jurassic in the Ross Sea region (Barrett and others, 1972). Sedimentation in the Pensacola Mountains area apparently terminated in the Permian, however, owing to orogenic uplift. The Neptune Group and Dover Sandstone probably correlate with the Taylor Group near the Ross Sea. The Dover may also correlate with the Crashsite Quartzite in the Ellsworth Mountains (Schopf, 1969). The Gale Mudstone and Pecora Formation probably correlate with the lower part of the Victoria Group near the Ross Sea. Late Paleozoic glaciation was widespread in Antarctica, but dating is poor in the general absence of diagnostic fossils. The Gale Mudstone probably also correlates approximately with the Darwin Tillite, Buckeye Tillite, and Pagoda Formation elsewhere in the Transantarctic Mountains (Barrett and others, 1972) and with the Whiteout Conglomerate in the Ellsworth Mountains (Schopf, 1969). Units in the 
Pensacola Mountains probably also have equivalents in the Shackleton Range (Stephenson, 1966; Clarkson, 1972) and possibly in western Queen Maud Land (Juckes, 1972).

The Patuxent Formation, consisting of metasedimentary rocks of pre-Beacon age, probably is also widely correlatable, but paleontologic dating is poor and interpretation of radiometric ages (Eastin and Faure, 1972) is complicated by resetting.

Basaltic igneous activity, both intrusive and extrusive, was widespread in Antarctica in mid-Mesozoic time. The Dufek intrusion correlates approximately with the Ferrar Group of Grindley (1963), which in the Ross Sea sector of the Transantarctic Mountains includes the Ferrar Dolerite and the Kirkpatrick Basalt. Similar mafic intrusive rocks of this age are reported from the Shackleton Range area (Stephenson, 1966) and western Queen Maud Land (Juckes, 1972). The Dufek intrusion is by far the largest single differentiated intrusive body of Ferrar age known in Antarctica. However, smaller layered intrusions are known in the Ferrar Group (Gunn, 1963; Grapes and Reid, 1971).

\section{SYNOPSIS OF GEOPHYSICAL STUDIES}

GRAVITY AND AEROMAGNETIC DAT A

Results of gravity and aeromagnetic surveys in the Pensacola Mountains are discussed by Behrendt and others (1974). The geologic map of the Davis Valley and part of the Cordiner Peaks quadrangles should be used in conjunction with the aeromagnetic intensity and simple Bouguer gravity maps of Behrendt and others (1973), which are also of $1: 250,000$ scale, as an aid in interpreting the geology of the extensive ice-covered regions. The location of the contact of the Dufek intrusion on this sheet is based largely on the geophysical anomaly maps.

A broad, regional Bouguer gravity gradient crosses the Pensacola Mountains. Values range from $82 \mathrm{mgal}$ in the northwest, over Ronne Ice Shelf, to $-90 \mathrm{mgal}$ in the northern Neptune Range. Values over the mapped extent of the Dufek intrusion range from 40 mgal in the northwest to $-60 \mathrm{mgal}$ in the southeast. Theoretical models based on the gravity data suggest either crustal thinning northwestward across the west front of the Pensacola Mountains, or the presence of a steep faultlike step at the crust-mantle interface along this front.

The mass effect of the Dufek intrusion is superimposed upon and distorts the regional gravity gradient. The exact gravity effect of the intrusion cannot be calculated from available data, but the maximum effect is estimated to be about $85 \mathrm{mgal}$. Assuming a reasonable range of density contrast of $0.27-0.33$ $\mathrm{g} / \mathrm{cm}^{3}$, this corresponds to about $8.8-6.2 \mathrm{~km}$ for total thickness of the Dufek intrusion, according to Behrendt and others (1974, p. 13). Using gravity data from the southwest end of Dufek Massif, where the lowest part of the body is exposed, and an assumed density contrast of $0.27 \mathrm{~g} / \mathrm{cm}^{3}$, the basal unexposed part of the intrusion is estimated to be $1.8-3.5 \mathrm{~km}$ thick.

Aeromagnetic anomalies of nearly 2,000 gammas, from peak to trough, are associated with the Dufek intrusion. In the map area, anomalies are highest - about 1,000 gammas - over Mount Malville in the Forrestal Range. Maximum anomalies are lower - about 400 gammas - in the northeast end of Dufek Massif near Davis Valley and are still lower toward the west end of the massif. The high magnetic anomalies, accordingly, are clearly associated with the magnetite-bearing to magnetite-rich gabbroic cumulates of the upper part of the intrusion.

The aeromagnetic and gravity data indicate that the Dufek intrusion extends for great distances northeastward and northward beneath the sheet of continental ice. Aeromagnetic anomalies extend to the edge of the surveyed region, and thus the full extent of the body is unknown. The magnetic survey indicates that the intrusion is at least about $24,000 \mathrm{~km}^{2}$ in area, and gravity data suggest that it has an additional area of 10,000 $\mathrm{km}^{2}$, according to Behrendt and others (1974).

\section{PALEOMAGNETIC DATA}

Paleomagnetic properties of rocks of the Dufek intrusion are discussed by Beck and others (1968), Griffin (1969), Beck and Griffin (1971), and Beck (1972). Intensity of natural remanent magnetization and magnetic susceptibility generally increase with height in the intrusion. Both normal and reversed polarities are present and may have resulted from either a self-reversal or a geomagnetic field-reversal mechanism. The paleomagnetic pole position for the body is at lat $56.5^{\circ} \mathrm{S}$, long $168^{\circ} \mathrm{W}$, near poles reported for the Jurassic Ferrar Dolerite from elsewhere in the Transantarctic Mountains.

The paleomagnetic studies reported by Beck and Schmidt (1971) show that regional heating apparently associated with the Triassic Weddell orogeny in the Pensacola Mountains resulted in the resetting of remanent magnetization directions of Cambrian volcanic rocks in the southern Neptune Range.

\section{REFERENCES CITED}

Aughenbaugh, N. B., 1961, Preliminary report on the geology of the Dufek Massif: Internatl. Geophys. Year World Data Center A, Glaciology, Glac. Rept. 4, p. 155-193.

Barrett, P. J., Grindley, G. W., and Webb, P. N., 1972, The Beacon Supergroup of east Antarctica, in Adie, R. J., ed., Antarctic geology and geophysics: Oslo, Universitetsforlaget, p. 319-332.

Beck, M. E., Jr., 1972, Palaeomagnetism and magnetic polarity zones in the Jurassic Dufek intrusion, Pensacola Mountains, Antarctica: Royal Astron. Soc. Geophys. Jour., v. 28, p. 49-63.

Beck, M. E., Jr., Ford, A. B., and Boyd, W. W., Jr., 1968 , Paleomagnetism of a stratiform mafic intrusion in the Pensacola Mountains, Antarctica: Nature, v. 217 , p. 534-535.

Beck, M. E., Jr., and Griffin, N. L., 1971, Magnetic intensities in a differentiated gabbroic body, the 
Dufek intrusion, Pensacola Mountains, Antarctica, in Geological Survey research 1971: U.S. Geol. Survey Prof. Paper 750-B, p. B117-B121.

Beck, M. E., Jr., and Schmidt, D. L., 1971, Reset direction of remanent magnetization for Upper Cambrian rhyodacitic welded tuff, Pensacola Mountains, Antarctica, in Geological Survey research 1971: U.S. Geol. Survey Prof. Paper 750-C, p. C174-C178.

Behrendt, J. C., Henderson, J. R., Meister, Laurent, and Rambo, W. L., 1974, Geophysical investigations of the Pensacola Mountains and adjacent glacierized areas of Antarctica: U.S. Geol. Survey Prof. Paper $844,28 \mathrm{p}$.

Behrendt, J. C., Rambo, W. L., Henderson, J. R., Wanous, R. E., and Meister, Laurent, 1973, Simple bouguer gravity and aeromagnetic maps of the Davis Valley quadrangle and part of the Cordiner Peaks quadrangle and vicinity, Antarctica: U.S. Geol. Survey Geophys. Inv. Map GP-887.

Cameron, R. E., and Ford, A. B., 1974, Baseline analyses of soils from Mount Lechner and Cordiner Peaks, Pensacola Mountains, Antarctica: Antarctic Jour. U.S., v. 9, no. 4, p. 116-119.

Clarkson, P. D., 1972, Geology of the Shackleton Range: a preliminary report: British Antarctic Survey Bull. 31, p. 1-15.

Craddock, Campbell, 1972, Antarctic tectonics, in Adie, R. J., ed., Antarctic geology and geophysics: Oslo, Universitetsforlaget, p. 449-455.

Dalziel, I. W. D., and Elliot, D. H., 1973, The Scotia Arc and Antarctic margin, in Nairn, A. E. M., and Stehli, F. G., ed., The ocean basins and margins, v. 1 : New York, Plenum, p. 171-246.

Eastin, Rene, and Faure, Gunter, 1972, Geochronology of the basement rocks of the Pensacola Mountains, Antarctica (abs.): Geol. Soc. America Abs. with Programs, v. 4, no. 7, p. 496.

Elliot, D. H., 1975, Tectonics of Antarctica: a review: Amer. Jour. Science, v. 275-A, p. 45-106.

Ford, A. B., 1968, Origin of microfractures and joints in the Dufek intrusion, Antarctica (abs.): Geol. Soc. America Spec. Paper 115, p. 325.

1970 , Development of the layered series and capping granophyre of the Dufek intrusion of Antarctica, in Visser, D. J. L., and Von Gruenewaldt, Gerhard, ed., Symposium on the Bushveld Igneous Complex and other layered intrusions: Geol. Soc. South Africa, Spec. Pub. No. 1, P. 492-510. 1972, The Weddell orogeny - latest Permian to early Mesozoic deformation at the Weddell Sea margin of the Transantarctic Mountains, in Adie, R. J., ed., Antarctic geology and geophysics: Oslo, Universitetsforlaget, p. 419-425.

1974, Basalt dikes of the Cordiner Peaks, Pensacola Mountains, Antarctica--satellitic bodies of the Dufek intrusion?: Antarctic Jour. U.S., v. 9 , no. 4 , p. 149-153.

1976, Stratigraphy of the layered Dufek intrusion of Antarctica: U.S. Geol. Survey Bull.
1405-D, p. D1-D36.

Ford, A. B., and Boyd, W. W., Jr., 1968, The Dufek intrusion, a major stratiform gabbroic body in the Pensacola Mountains, Antarctica: Internat. Geol. Cong., 23d, Proc., v. 2, p. 213-228.

Ford, A. B., and Nelson, S. W., 1972, Density of the stratiform Dufek intrusion, Pensacola Mountains, Antarctica: Antarctic Jour. U.S., v. 7, no. 5, p. 147-149.

Ford, A. B., Schmidt, D. L., Boyd, W. W., Jr., and Nelson, W. H., 1978, Geologic map of the Saratoga Table quadrangle, Pensacola Mountains, Antarctica: U. S. Geol. Survey Antarctic Geol. Map A-9, scale 1:250,000.

Grapes, R. H., and Reid, D. L., 1971, Rhythmic layering and multiple intrusion in the Ferrar Dolerite of south Victoria Land, Antarctica: New Zealand Jour. Geology and Geophysics, v. 14, p. $600-604$.

Griffin, N. L., 1969, Paleomagnetic properties of the Dufek intrusion, Pensacola Mountains, Antarctica: California Univ., Riverside, M.S. thesis, 93 p.

Grindley, G. W., 1963, The geology of the Queen Alexandra Range, Beardmore Glacier, Ross Dependency, Antarctica; with notes on the correlation of Gondwana sequences: New Zealand Jour. Geology and Geophysics, v. 6, p. 307-347.

Gunn, B. M. 1963, Layered intrusions in the Ferrar Dolerites, Antarctica: Mineral. Soc. America Spec. Paper 1, p. 124-133.

Himmelberg, G. R., and Ford, A. B., 1973, Pyroxene compositional trends in the Dufek intrusion, Pensacola Mountains, Antarctica: Antarctic Jour. U.S., v. 8, p. 260-263.

1975, Petrologic studies of the Dufek intrusion: iron-titanium oxides: Antarctic Jour. U.S., v. 10 , no. 5 , p. $241-244$.

1976, Pyroxenes of the Dufek intrusion, Antarctica: Jour. Petrology, v. 17, pt. 2, p. 219243.

1977, Iron-titanium oxides of the Dufek intrusion, Antarctica: Am. Mineralogist, v. 62, p. 623-633.

Huffman, J. W., and Schmidt, D. L., 1966, Pensacola Mountains project: Antarctic Jour. U.S., v. 1, no. 4, p. 123-124.

Jackson, E. D., 1967, Ultramafic cumulates in the Stillwater, Great Dyke, and Bushveld intrusions, in Wyllie, P. J., ed., Ultramafic and related rocks: New York, John Wiley and Sons, p. 20-38.

1971 , The origin of ultramafic rocks by cumulus processes: Fortschr. Mineralogie, v. 48, p. 128-174.

Juckes, L. M., 1972, The geology of north-eastern Heimefrontfjella, Dronning Maud Land: British Antarctic Survey, Sci. Report 65, 44 p.

Kovacs, Austin, and Abele, Gunars, 1974, Blue ice runway site survey, Pensacola Mountains: Antarctic Jour. U.S., v. 9, p. 175-177.

Neuburg, H. A. C., Thiel, Edward, Walker, P. T., Behrendt, J. C., Aughenbaugh, N. B., 1959, The 
Filchner Ice Shelf: Assoc. Am. Geographers

Annals, v. 49, no. 2, p. 110-119.

Palmer, A. R., and Gatehouse, C. G., 1972, Early and Middle Cambrian trilobites from Antarctica: U.S. Geol. Survey Prof. Paper 456-D, 37 p.

Schmidt, D. L., Dover, J. H., Ford, A. B., and Brown, R. D., Jr., 1964, Geology of the Patuxent Mountains in Adie, R. J., ed., Antarctic geology: New York, John Wiley and Sons, p. 276-283.

Schmidt, D. L., and Ford, A. B., 1969, Geologic map, with accompanying text, of the Pensacola and Thiel Mountains; sheet 5, Geologic maps of Antarctica: New York, Am. Geog. Soc., scale $1: 1,000,000$.

Schmidt, D. L., and Friedman, Irving, 1974, Continental deposition of Antarctic tillite indicated by carbon and oxygen isotopes: U.S. Geol. Survey Jour. Research, v. 2, no. 6, p. 711-715.

Schmidt, D. L., and Williams, P. L., 1969, Continental glaciation of late Paleozoic age, Pensacola Mountains, Antarctica, in Amos, A. J., ed., Gondwana stratigraphy, IUGS Symposium, Buenos Aires, October, 1967: UNESCO Earth Sci. Ser., v. 2, Paris, p. 617-649.

Schmidt, D. L., Williams, P. L., and Nelson, W. H., 1978 , Geologic map of the Schmidt Hills quadrangle and part of the Gambacorta Peak quadrangle,
Pensacola Mountains, Antarctica: U.S. Geol. Survey Antarctic Geol. Map A-8, scale 1:250,000.

Schmidt, D. L., Williams, P. L., Nelson, W. H., and Ege, J. R., 1965, Upper Precambrian and Paleozoic stratigraphy and structure of the Neptune Range, Antarctica, in Geological Survey research 1965: U.S. Geol. Survey Prof. Paper 525-D, p. D112-D119.

Schopf, J. M., 1968, Studies in Antarctic paleobotany: Antarctic Jour. U.S., v. 3, no. 5, p. 176-177. 1969, Ellsworth Mountains; position in west Antarctica due to sea-floor spreading: Science, v. 164, p. 63-66.

Stephenson, P. J., 1966, Geology, 1. Theron Mountains, Shackleton Range and Whichaway Nunataks: Trans-Antarctic Expedition, 1955-1958, Sci. Repts., no. 8, 79 p.

Wager, L. R., and Brown, G. M., 1968, Layered igneous rocks: Edinburgh, Oliver and Boyd, $558 \mathrm{p}$.

Walker, P. T., 1961, Study of some rocks and minerals from the Dufek Massif, Antarctica: Internatl. Geophys. Year World Data Center A, Glaciology, Glac. Report 4, p. 195-213.

Williams, P. L., 1969, Petrology of upper Precambrian and Paleozoic sandstones in the Pensacola Mountains, Antarctica: Jour. Sed. Petrology, v. 39, no. 4 , p. $1455-1465$. 